\title{
УДК 001(091):63:65.012
}

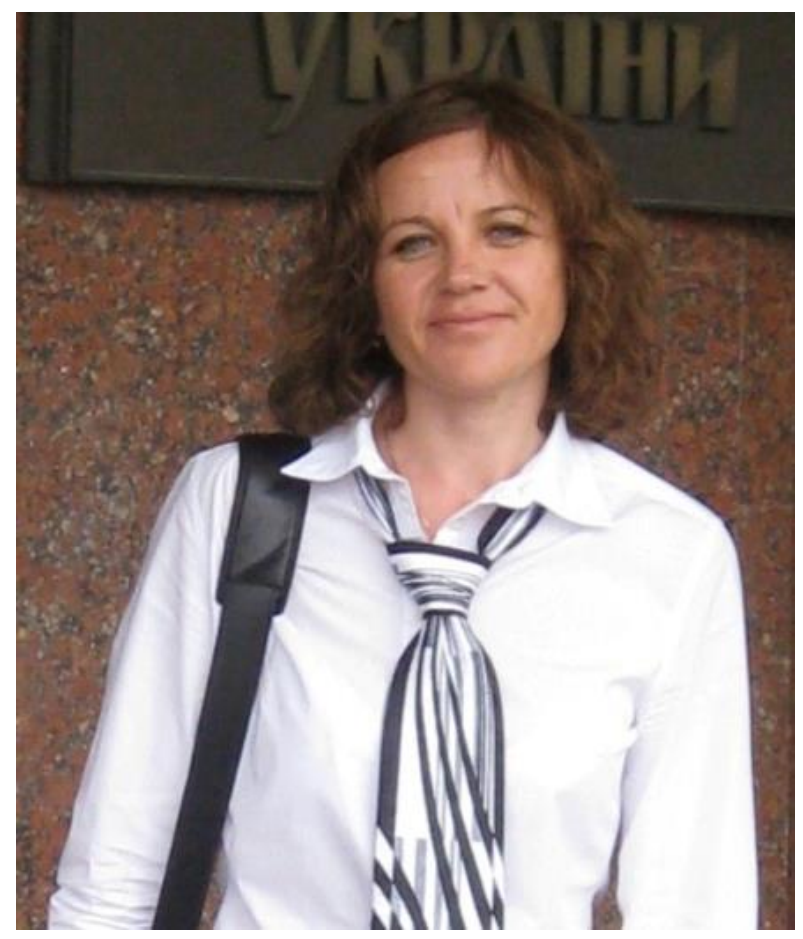

\section{ЩЕБЕТЮК \\ Наталія Борисівна,}

доктор історичних наук, старший науковий співробітник, Інститут історії аграрної науки, освіти і техніки ННСГБ НААН

Shchebetyuk@ukr.net (м. Київ)

\section{ТВОРЕННЯ НАУКОВОГО АГРАРНОГО ДИСКУРСУ НАПРИКІНЦІ 20-Х - У 30-I PP. XX СТ. В УСРР/УРСР}

Статтю присвячено розгляду процесу накопичення знань про становлення $\check{u}$ подальший розвиток науково-організаційних $i$ теоретико-методологічних засад аграрної науки й дослідної справи в означеному сегменті історичного шляху України. На основі застосування предметно-хронологічного та порівняльно-історичного методів висвітлено історіографічні напрачювання дослідників, що формують певні блоки стосовно хронології, тематики, методології. Встановлено, щуо історіографічні праџі радянської доби характеризуються різноплановістю тематичного наповнення видань та методологічних підходів, висвітлюють аспекти розвитку галузевої науки, сприяють критичному переосмисленню історичного прочесу, зокрема кіния 2030-х рр. ХХ ст. Сучасні дослідники на основі результатів опрачювання архівних матеріалів актуалізують вирімення загальних проблем становлення та подальшого розвитку вітчизняного дослідництва, створення нових напрямів $i$ вчень з урахуванням історичного досвіду провідних наукових шкіл $i$ персоніфікаиії історії аграрної науки України. 3'ясовано основоположну роль напрачювань В.В. Вінера, С.О. Захарова, С.П. Кулжсинського М.К. Недокучаєва О.К. Філіповського, О.А.Янати та ін. у формуванні теоретикометодологічного підгрунтя еволючиї вітчизняного галузевого експериментаторства в досліджуваний період. 
Ключові слова: аграрна наука, дослідна справа, інституалізація, історіографічні праці, історія розвитку, науково-організаційні засади, методологія.

\section{CREATION OF A SCIENTIFIC AGRARIAN DISCOURSE AT THE END OF THE 20S - IN THE 30S. XX century in the Ukrainian SSR}

The article is devoted to the consideration of the process of accumulating knowledge about the formation and further development of the scientificorganizational and theoretical-methodological foundations of agrarian science and research in this segment of the historical path of Ukraine. Based on the use of subject-chronological and comparative-historical methods, the historiographic developments of researchers are highlighted, which form certain blocks in relation to chronology, topics, methodology. It has been established that historiographic works of the Soviet era are characterized by a variety of thematic content of publications and methodological approaches, highlight aspects of the development of branch science, contribute to a critical rethinking of the historical process, in particular the late 1920s and 1930s. XX century. Modern researchers, based on the results of processing archival materials, actualize solutions to common problems of the formation and further development of domestic research, the creation of new directions and teachings, taking into account the historical experience of leading scientific schools and personification of the history of agricultural science in Ukraine. The fundamental role of V.V. Wienera, S.A. Zakharova, S.P. Kulzhinsky M.K. Nedokuchaeva, A.K. Filippovsky, A.A. Yanati et al. in the formation of a theoretical and methodological basis for the evolution of domestic industry experimentation in the period under study.

Key words: agricultural science, research, institutionalization, historiographic work, history of development, scientific and organizational foundations, methodology.

\section{СОЗДАНИЕ НАУЧНОГО АГРАРНОГО ДИСКУРСА В КОНЦЕ 20-Х - В}

\section{0-E ГГ. ХХ В. В УССР}

Статья посвящена рассмотрению процесса накопления знаний о становлении и дальнейтем развитии научно-организаџионных и теоретикометодологических основ аграрной науки и исследовательского дела в рассматриваемом сегменте исторического пути Украины. На основе применения предметно-хронологического и сравнительно-исторического методов освещены историографические наработки исследователей, которые формируют определенные блоки относительно хронологии, тематики, методологии. Установлено, что историографические труды советских времен характеризуются разноплановостью тематического наполнения изданий $u$ методологических подходов, освещают аспекты развития отраслевой науки, способствуют критическому переосмыслению исторического процесса, 8 частности конца 20-30-х г2. ХХ в. Современные исследователи на основе 
результатов обработки архивных материалов актуализируют решения общих проблем становления $u$ дальнейшего развития отечественного исследовательства, создание новых направлений $и$ учений с учетом исторического опыта ведущих научных школ и персонификачии истории аграрной науки Украины. Выяснено основополагающую роль наработок В.В. Винера, С.А. Захарова, С.П. Кулжинского М.К. Недокучаева, А.К. Филипповского, А.А.Янать $и$ др. в формировании теоретикометодологической основы эволюиии отечественного отраслевого экспериментаторства в исследуемый период.

Ключевые слова: аграрная наука, исследовательское дело, институализация, историографические работы, история развития, научноорганизаиионные основы, методология.

Дослідження історії становлення й розвитку сільськогосподарської науки України $є$ актуальним на сучасному етапі впровадження реформ в Україні й вирішення проблем у досягненні ефективності форм наукового забезпечення продуктивного розвитку аграрного сектору економіки держави, за яких врахування історичного досвіду, набутого в суперечливий період еволюційного поступу природничих наук, є невід'ємною складовою. Процес формування наукового дискурсу з проблематики розвитку аграрної науки в Україні наприкінці 20-х - у 30-і рр. ХX ст. відображає еволюцію аграрної наукової думки в історіографічному просторі та сприяє з'ясуванню питань, що потребують подальших поглиблених розвідок. Окремим напрямам з означеної проблеми приділили увагу науковці Інституту історії аграрної науки, освіти і техніки ННСГБ НААН, зокрема академік НААН В.А. Вергунов, професор І.С. Бородай та ін. [1, 2].

Метою даної статті є розгляд комплексу історіографічних напрацювань, що відображає процес накопичення наукових знань в сегменті розвитку теорії, практики й організації аграрного дослідництва в Україні кінця 20-х - у 30-і pp. $\mathrm{XX}$ ст. 3 використанням традиційного хронологічного поділу на радянський період і добу незалежності України, наукові розвідки розглянуто в межах трьох блоків: розвиток сільськогосподарської науки й дослідної справи; діяльність Всеукраїнської академії сільськогосподарських наук (ВУАСГН); теоретикометодологічні основи еволюції основних напрямів аграрної науки. 
До перших історіографічних напрацювань, які розкривають науковоорганізаційні аспекти сільськогосподарської дослідної справи в Україні належать невеликі за обсягом публікації середини та більшою мірою кінця 20х pp. ХХ ст. Насамперед, це праці В.В. Вінера [3], С.П. Кулжинського [4], О.Н. Соколовського [5], О.А. Янати [6], автори яких висвітлюють обласний принцип побудови галузевого дослідництва, який супроводжувався не лише фінансовими труднощами, але i проблемами методологічного характеру. Відзначимо комплексні праці «Вступ до агрономії» С.О. Захарова [7] та за такою самою назвою автора В.С. Смиренномудренського [88]. Вони системно обгрунтовують теоретичні основи еволюції сільськогосподарської дослідної справи та формування іiі методологічного інструментарію. Висвітлюючи історичний шлях галузевої освіти й дослідництва, С.О. Захаров зазначає, що вища сільськогосподарська освіта Росії запозичила досвід Німеччини i відповідно пройшла такі самі етапи становлення.

Доступною мовою виклав основні засади i досягнення сільськогосподарської дослідної справи В.М. Румянцев [9], ставлячи мету, як він сам пише, донести практичні рекомендації до селянства. Автор не лише описав найголовніші досягнення дослідних станцій з різних напрямів упродовж 1920-х pр., але і розкрив суть дослідної справи, іï побудову та організацію роботи цієї інституції, пристосованої до конкретних сільськогосподарських районів України. Він акцентував увагу на їхній різноманітності, які потрібно обов'язково враховувати при веденні господарства. У наступній праці В.М. Румянцев [10] стисло відзначив результати діяльності створеної у 1929 р. Всесоюзної академії сільськогосподарських наук ім. В.І. Леніна та завдання, поставлені перед сільськогосподарською наукою, які передбачали інтенсивне впровадження у короткі терміни усіх досягнень, включно із закордонними, у виробництво i таким чином забезпечення бази для швидкого зростання соціалістичного сільського господарства. Це єдина узагальнююча праця про роботу реорганізованої мережі сільськогосподарських науково-дослідних установ СРСР за два роки діяльності. У виданні зазначено, що організаційний 
період був успішним і мережа установ є стабілізованою. Вона охоплювала 58 науково-дослідних інститутів і понад 400 зональних станцій, де працювали понад 16 тис. наукових співробітників $[10$, с. 5]. Автор подає основні досягнення останніх років з різних галузей сільськогосподарської науки, проте не називає прізвищ виконавців і не вказує, в якій установі виконано роботу.

Неординарністю вирізняється підручник О.К. Філіповського «Сільськогосподарська дослідна справа» [11], який тривалий час залишається єдиним у такому роді, з розглядом еволюції поглядів на методи проведення дослідів, вивчення сільськогосподарських явищ та їх впливу, методів дослідження та ін. Останній розділ підручника висвітлює історію розвитку дослідних установ та отримані ними результати. Автор зазначає, що сільськогосподарська дослідна справа $\epsilon$ потужним чинником розвитку сільського господарства, а вивчення ії методів має таке саме значення, як усі інші науково-технічні дослідження, спрямовані на розвиток науки і техніки.

Важливими напрацюваннями в історіографічному комплексі вирізняються праці М.К. Недокучаєва, що містять окремі частини, присвячені виникненню й розвитку сільськогосподарської дослідної справи [1213; 1312]. Також автор аналізує основи побудови сільськогосподарської дослідної справи на межі 2030-х рр. ХХ ст. та наводить деякі рекомендації щодо їх покращення, зокрема, обгрунтовує вже відомий принцип щодо проектування програм досліджень згідно 3 вимогами економіки та їх застосування відповідно до природнокліматичних зон країни.

Невеликим екскурсом в історію становлення принципів організації дослідної справи $є$ наукові праці С. Машури [14], I. Теплова [15], Ю. Гомона [1616]. На основі узагальнень й аналізу існуючого крайового принципу організації наукового забезпечення сільського господарства автори запропонували свої проекти, орієнтовані на обслуговування колективних господарств. Видрукувана наукова доповідь А.М. Сліпанського [17] є однією 3 перших робіт історіографічного характеру, що розкриває діяльність Всеукраїнської академії сільськогосподарських наук. Автор зосередив увагу на 
укрупненні соціалістичних форм господарювання, яке вимагало поглибленої спеціалізації й побудови системи науково-дослідних установ ВУАСГН відповідно до районів спеціалізації сільськогосподарського виробництва.

Окремі аспекти діяльності мережі науково-дослідних установ ВУАСГН висвітлюють автори тематичного збірника «За підвищення врожайності» Б. Бламквіст, Г. Гоппе, Я. Классен, В. Ротмістров, А. Сліпанський та О. Соколовський [18]. У виданні зазначено, що всі галузі сільського господарства в Україні мають свою спеціалізовану науково-дослідну установу, яка через систему опорних пунктів пов'язує роботу з господарством, це 8 галузевих інститутів союзного та 11 республіканського значення, 10 всеукраїнських станцій, 239 опорних пунктів цих інститутів та станцій. У наукових установах працювало понад 2 тис. співробітників, у 1932 р. навчалося близько 1000 аспірантів [18, с. 23]. Цінними є видання досліджуваного періоду, що відображають розвиток сільськогосподарської дослідної справи в агрогрунтознавстві 30-х pp. ХХ ст. за авторством Г.Г. Махова [19]. Автор висвітлив історію дослідної справи в агрогрунтознавстві та основні його досягнення на території України. Також історичному екскурсу присвячена праця Д.Г. Віленського [20].

Привертає увагу історіографічним наповненням колективне видання «Научно-исследовательский институт свиноводства. К итогам десятилетней работы Института. 1930-1940» [21]. Створений на базі однієї з найдавніших дослідних установ, інститут мав результативні напрацювання 3 питань фізіології й обміну речовин у свиней; їх годівлі, утримання та відгодівлі, вирощування молодняку; розведення і селекції свиней; механізації процесів, пов'язаних 3 утриманням тварин. Відрізняється змістовністю праця П.Т. Дмитренка «Харківський ордена Трудового Червоного Прапора сільськогосподарський інститут» [22], яка $є$ коротким історичним оглядом становлення й діяльності навчального закладу упродовж столітнього існування 3 висвітленням здобутків з різних напрямів сільськогосподарської науки. У 1930-х pp. лісовий факультет інституту став основою для заснування 
Київського лісогосподарського інституту, а меліоративний факультет Київського гідромеліоративного інституту. Упродовж 1930-1940 pp. Інститут підготував 1570 висококваліфікованих агрономів, а за ознакою кваліфікації кадрів у СРСР посідав друге місце після Московської сільськогосподарської академії ім. К.А. Тимірязєва.

Надалі публікації з історичною компонентою майже повністю зникають 3 наукового обігу і з'являються лише у середині 50-х рр. ХХ ст., що чітко свідчить про потужний вплив політико-ідеологічних чинників. Цінну групу становлять комплексні праці, що розкривають теоретичні основи, методологію та сутність сільськогосподарської дослідної справи. Вони містять окремі розділи, які у стислому вигляді показують еволюційний поступ дослідництва. До таких праць належить російське видання П.Н. Константінова «Основы сельскохозяйственного опытного дела» (1952), яке включає розділ «Краткая история сельскохозяйственного опытного дела и современная структура его в СССР» [23]. Стосовно досліджуваного періоду автор зазначає про реорганізаційні заходи в управлінні та координації діяльністю науководослідних установ СРСР загалом і союзних республік зокрема. Він наголошує, що після реформування у 1934 р. ВАСГНІЛ у зв'язку з невиконанням покладених на неї завдань, у ії системі залишилось 14 інститутів зі 111-ти [23, c. 48]. Подібним чином були перепідпорядковані НКЗС СРСР дослідні станції й інші структурні одиниці. Крім того, П.Н. Константінов зауважує про потребу розгляду історії розвитку вузьких спеціальних та суміжних з ними спеціальних дисциплін, передусім грунтознавства, рослинництва, селекції рослин і тварин, фізіології, агрохімії, біохімії, фітопатології, ентомології та ін.

Неабиякий інтерес становить праця А.О. Вербіна «У истоков отечественной агрономии» [24], що висвітлює еволюційний шлях сільськогосподарської дослідної справи у дорадянський період, якого автор торкається лише побіжно. Проте цю працю можна розглядати як узагальнюючу 3 детальним розкриттям здобутків дослідництва, його методології, що сприяє розумінню передумов процесу інститутизації, яка відбулася наприкінці 20-х рр. 
XX ст. До названої групи праць варто віднести працю Б.М. Рожественського «Методика опытно-исследовательского дела по полеводству», надруковану 3 неопублікованої спадщини вченого у 1958 р. за ініціативи УНДІ рослинництва, селекції і генетики [25]. У цій праці вчений торкається й питань методики сільськогосподарської дослідної справи в історичному аспекті. Зокрема він зазначає, що ï методологи - В.Г. Ротмістров, М.К. Недокучаєв, І.В. Іванов та П.Н. Константінов, розглядали методику польових досліджень лише з позиції технічних досліджень і недостатньо уваги приділили методам поєднання технічних досліджень з виробничим процесом, а також методиці передачі отриманих результатів господарствам.

Широкому колу науковців відома праця професора, доктора сільськогосподарських наук В.І. Сазанова «Сельскохозяйственное опытное дело в растениеводстве и его методика» (1962) [26]. У передмові до видання в стислому викладі подано історію виникнення й становлення сільськогосподарської дослідної справи в Україні, що, як відомо, відбувалося за умов «спільної Вітчизни» російського і українського народів. Автор висвітлив систему організації науково-дослідних установ сільськогосподарської галузі, становлення якої відбулося наприкінці $20-\mathrm{x} \mathrm{pp.} \mathrm{XX} \mathrm{ст.} \mathrm{і} \mathrm{яка,} \mathrm{пройшовши} \mathrm{крізь}$ часові видозміни, за своєю суттю залишилася дієвою й донині. Отже, важливо зазначити, що праці методологів сільськогосподарської дослідної справи, які містять історіографічні розділи, позбавлені характерної радянській історіографії ідеологічної надбудови. Те саме простежується у наукових публікаціях, присвячених окремим напрямам сільськогосподарської науки. Зокрема, особливості розвитку лісової типології висвітлив Д.Д. Лавриненко [27], підтримуючи визнання лісу «як єдності організмів і середовища». У розвитку лісового господарства України тридцяті роки відзначилися широким розгортанням лісокультурних робіт, особливо після виходу постанови уряду СРСР у липні 1936 р., якою було виділено водоохоронну зону лісів, куди увійшла й територія України. Це вимагало від дослідників опрацювання науково обгрунтованих рекомендацій щодо 
створення лісових культур. Так, у 1930 р. складено типи лісових культур для лісокультурної зони України, розроблені за типами лісу Є.В. Алексєєва. У 1935 р. аналогічні типи склали співробітники кафедри лісівництва і лісових культур Київського лісотехнічного інституту для лісопромислової зони України. У 1936 р. видано опрацьовані Українським науково-дослідним інститутом лісового господарства та агролісомеліорації рекомендації із створення культур у Лісостепу (П.В. Биков, П.П. Кожевников, С.С. П’ятницький «Лісові культури, Лісостепова частина УРСР»), в яких типи культур і агротехніка їх створення пов'язані з типами умов місцезростання i станом лісокультурної площі. У 1938 р. П.С. Погребняк разом 3 Л.М. Вербицьким склали типи лісових культур для України, схвалені нарадою виробничників при Центральній лісовій дослідній станції УРСР.

Досягнення вітчизняних селекціонерів, основоположників селекційної справи в Україні - В.Я. Юр'єва, А.О. Сапегіна, Л.І. Ковалєвського, В.Є. Желтковича, І.М. Єремеєва та інших висвітлив І.М. Поляков [28]. У 1923 р. в Україні організовано першу мережу сортовипробування, а з 1924 р. системно проводили апробацію сортових посівів. У 1927-1929 рр. кращі з перших сортів, що пройшли державне випробування, районували й впровадили у виробництво. Серед озимих пшениць у першому районуванні були такі сорти: Дюрабль (Іванівської станції), Українка 0246 (Миронівської), Еритроспермум 917, Альбідум 676 і Мільтурум 120 (Харківської), Кооператорка, Земка й Степнячка (Одеської станції) та місцевий сорт Кримка. Із сортів ярої пшениці прямого добору вперше в Україні були районовані 3 сорти Харківської селекції Мільтурум 162, Гордеіформе 808 та Арнаутка Харківська. Наприкінці 1930-х років створено й районовано ще кілька врожайних сортів гібридного походження. Так, у 1938 р. у виробництво надійшли сорт Одеська 3, свого часу він займав великі площі посівів, а також сорти вузького ареалу Лютесценс 9 i Лютесценс 74. У 1940 p. районовані ще 2 сорти - Лютесценс 17 i Еритроспермум 15, що відзначалися високою продуктивністю і якістю зерна.

Реорганізаційні заходи щодо діяльності Українського науково-дослідного 
інституту тваринництва висвітлено в узагальнюючих працях Полтавської сільськогосподарської станції, які містять розділи історичних нарисів [29; 30]. Установа забезпечувала науковий супровід тваринницької галузі Харківської, Донецької, Дніпропетровської та Одеської областей. Київська дослідна станція тваринництва (м. Біла Церква) вела науково-дослідну роботу для потреб тваринницької галузі Київської, Вінницької та Чернігівської областей. Окремі аспекти вивчення грунтового покриву, проектування земельних площ під зрошення й гідробудівництво на півдні України у 30-х рp. ХХ ст. висвітлює Г.С.Гринь, зазначає про складення й видання карти грунтів України в масштабах $1: 10000$ i $1: 750000$ та грунтово-агрохімічної карти зони бурякосіяння [31].

Радянську історіографію наповнює низка видань, зокрема «Соціалістична перебудова і технічна реконструкція сільського господарства України (19271932)» за авторством I.I. Слинька [32]. Із залученням архівних матеріалів він висвітлює процес формування передумов соціалістичної перебудови сільського господарства, роль МТС у зміцненні колгоспного руху, розгортання суцільної колективізації. Також автор описує «складності у хлібозаготівлях» 19311932 pp., робить узагальнюючі висновки щодо потреби організаційногосподарського зміцнення колгоспів і радгоспів, а також підготовки фахівців сільськогосподарського профілю. Досягненням сільського господарства за 50 років радянської влади з урахуванням особливостей землеробства і методів вирощування провідних культур певних районів, областей та господарств присвячено працю I.I. Синягіна [33], в якій автор систематизовано розглянув окремі напрями господарювання. У колективній праці, виданій до 75-річчя створення Української ордена Трудового Червоного Прапора сільськогосподарської академії (нині - Національний університет біоресурсів і природокористування України) висвітлено історичний шлях цього вищого навчального закладу [34]. Досліджуваного періоду автори торкаються лише побіжно. Наступне видання В.В. Діденка [35] містить більш об'єктивну 
інформацію про діяльність одного 3 провідних освітянських закладів із підготовки фахівців для сільського господарства.

Характеризуючи стан наукової розробки проблеми дослідження у радянський період, зазначимо, що історіографічні напрацювання характеризуються різноплановістю тематичного наповнення видань та методологічних підходів. Представлені до розгляду й аналізу наукові видання висвітлюють певні аспекти розвитку аграрної науки наприкінці 20-х - у 30$\mathrm{x}$ роках XX ст. Детально опрацьовано питання теорії i методології сільськогосподарської дослідної справи у публікаціях кінця 20-х рр. та середини 50-х pp. XX cr. Інформативний потенціал проаналізованих історіографічних напрацювань $\epsilon$ змістовним i сприяє критичному переосмисленню історичного процесу, зокрема кінця 20-30-х рр. XX ст.

Новими методологічними підходами привертають увагу напрацювання російських дослідників наприкінці 80-х - у 90-х рр. ХХ ст. Насамперед це наукові праці послідовників репресованих учених. До таких належать вибрані твори О.В. Чаянова «Крестьянское хозяйство» [36], основними питаннями в яких $\epsilon$ розгляд проблем диференціювання селянського господарства, визначення собівартості продуктів, організації виробництва в сімейному селянському господарстві наприкінці 20-х pp. XX ст. До значних здобутків зарубіжної історіографії еволюції аграрної науки належить праця О.О. Ніконова «Спираль многовековой драмы: аграрная наука и политика России (XVIII-XX вв.)» [37]. На основі аналізу великої низки різнопланових джерел і матеріалів автор розкрив концепції окремих наукових шкіл та погляди видатних учених у різні історичні періоди в контексті суспільнополітичних і соціально-економічних змін у Росії. Автор висвітлив діяльність ВАСГНІЛ і відповідно науково-дослідних установ сільськогосподарської галузі України. В праці І.В. Іванова «История отечественного почвоведения. Развитие идей, дифференциация, институализация» [38] детально охарактеризовано періоди історії грунтознавства, наукові здобутки провідних грунтознавців та діяльність науково-дослідних інституцій. 
3 українських видань у 1988 р. виходить друком монографія «Развитие механизации и электрификации сельского хозяйства Украинской ССР» [39], в якій комплексно висвітлено історію розвитку механізації та електрифікації сільського господарства України, показано процес створення і впровадження у виробництво сільськогосподарської техніки, проведення наукових досліджень, підготовку інженерно-технічних спеціалістів та ін. Із середини 90-х рр. ХХ ст. у наукових обіг входять напрацювання вітчизняних дослідників 3 новими методологічними підходами. Однією 3 перших стала праця В. І. Онопрієнка «Історія української науки XIX-XX століть» [40]. Автор вперше подав цілісну картину становлення й розвитку науки в Україні, а саме формування інституцій, наукових шкіл, досягнення вчених. Відзначено позитивний вплив інститутизації наприкінці 20-х рр. XX ст., суперечливий розвиток науки у 30i pp. під впливом репресивної системи. Втрати української науки B.І. Онопрієнко висвітлив у своєму попередньому виданні «Репресована наука України» [41]. Зауважимо, що вони безвимірні, і відновлення забутих або невідомих імен ще триватиме довго. До цієї групи праць належать результати творчих пошуків В.В. Ткаченка [42]. Дослідник аналізує розвиток вітчизняної науки у 20-30-х роках минулого століття як складову соціокультурного простору суспільства, важливий чинник формування української нації. Також приділено певну увагу характерним особливостям наукового забезпечення сільськогосподарської галузі у досліджуваний нами періоду.

Вчені-аграрії України також розпочали процес регенерації історичного шляху аграрної науки. Цінним історіографічним надбанням стало колективне видання «Українська академія аграрних наук. 1991-1995» 3 передмовою «Сторінки історії» [43]. Автори здійснили спробу вперше незаангажовано розкрити науково-організаційні етапи, через які довелося пройти сучасній Національній академії аграрних наук України. Видання також містить розділ присвячений мережі науково-дослідних установ Академії в розрізі відділень, опис діяльності яких подано разом з історичною довідкою. Певну групу формує серійний комплекс історіографічних напрацювань біографічного 
характеру «Українські вчені-аграрії XX ст.», що диференційовано відтворюють внесок видатних учених у розвиток сільськогосподарської науки України [44-50]. Інтерес для дослідників також становить чотиритомна добірка оглядових і експериментальних статей чисельного колективу авторів членів Українського товариства генетиків і селекціонерів ім. М.І. Вавилова «Генетика і селекція в Україні на межі тисячоліть» [51]. Із залученням грунтовного фактологічного матеріалу науковці висвітлюють історію та розвиток досліджень з проблем генетики і селекції в Україні, зокрема і в досліджуваний нами період.

32001 р. розпочав свою діяльність Інститут історії аграрної науки, освіти i техніки ННСГБ НААН під керівництвом В.А. Вергунова. Результати досліджень інституту друкуються у 13 серіях, серед яких вирізняються «Аграрна наука України в особах, документах, бібліографії» та «Біобібліографія вчених-аграріїв України». Видання серій відображають еволюцію аграрної наукової думки з різних галузевих напрямів, становлення і діяльність науково-дослідних установ, а також персоніфікований внесок визначних учених. Серед основних праць відзначимо видання В.А. Вергунова, що торкаються доби 30-х pp. ХX ст. - «Полтавське дослідне поле : становлення і розвиток сільськогосподарської дослідної справи в Україні (до 125-річчя державного дослідництва в агрономії та тваринництві)» [52], «Сільськогосподарська дослідна справа в Україні від зародження до академічного існування : організаційний аспект» [53] та ін. Окремий комплекс формують біографічні покажчики наукових праць учених з різних напрямів розвитку сільськогосподарської науки в Україні, зокрема присвячені О.А. Янаті [54], Г.Г. Махову [55] та ін. Також вийшли друком видання монографічного характеру, що контекстово на основі узагальнень архівних матеріалів й друкованих праць подають життєпис та висвітлюють наукову спадщину видатних науковців, організаторів сільськогосподарської дослідної справи 3 різних галузевих напрямів - О.Н. Соколовського [56], О.В. Квасницького [57], А.О. Сапєгіна [58]. 
Аналіз історіографічних напрацювань останніх десятиріч засвідчив наявність певної кількості узагальнюючих праць, які умовно розподіляються за напрямами аграрної науки, відтворюючи розвиток їх наукового забезпечення, зокрема наприкінці 20-х - у 30-і pp. XX ст. Зауважимо, що найбільш дослідженим виявилося грунтознавство як основоположна складова природознавчої науки. Розкриттю еволюційного поступу вітчизняного грунтознавства присвячено численні наукові публікації, насамперед В. А. Вергунова [59], О.М. Грінченка [60], В.Ф. Сайка [61] та ін. В.А. Вергунов вперше за часи незалежності виділив етапи становлення й розвитку українського наукового грунтознавства, застосувавши принципи науковості, системності та історизму, обгрунтував методологію.

У спеціальній праці поряд із висвітленням питань біології, морфології та особливостей будови рослини пшениці В.В. Шелепов [62] розкриває походження, значення культури пшениці й еволюцію селекційних досліджень в Україні. На основі власних досліджень автор подає методи селекції пшениці у умовах Степу i Лісостепу, зазначаючи про пшеницю як найдавнішу національну культуру. Детально дослідила внесок науково-дослідних установ та окремих учених у становлення селекції пшениці в Україні Х.М. Піпан [63]. Авторкою розглянуто передумови становлення й розвиток селекції озимої пшениці в Україні від зародження до сьогодення. Відображено основні результати народної, аналітичної та наукової селекції щодо покращання сортів названої культури, розкрито й узагальнено генеруючий внесок вітчизняних провідних селекціонерів.

Відтворює історію розвитку науково-організаційних основ застосування вітчизняних сівозмін у системах землеробства Н.П. Коваленко [64]. На основі аналізу архівних матеріалів авторка довела важливість внеску науководослідних установ i навчальних закладів у становлення теоретикометодологічних і практичних знань про сівозміни. У $30-\mathrm{x}$ р. намагалися впроваджувати спеціалізовані сівозміни з внесенням органічних і мінеральних добрив та сівозміни з чистими і зайнятими парами. Еволюцію реформування 
аграрного сектору економіки, історичний шлях розвитку аграрної економіки в Україні від часів скасування кріпосного права i до дня проголошення незалежності Української держави розкрито у праці «Аграрна економіка i політика в Україні: підсумки минулого та погляд у майбутнє» [65]. Особливості розвитку садівництва у 30-х pp. ХХ ст. та його наукового забезпечення висвітлено у виданні «Садівнича наука України: минуле, сьогодення, перспективи» авторів І. К. Омельченка і І. В. Гринника [66]. Зазначено, що у 30х pp. ХХ ст. розширилися площі під плодовими садами, у 1940 р. понад 2300 господарств мали від 20 до 100 га плодових насаджень.

Теоретико-методологічні основи становлення й розвитку вітчизняної зоотехнічної науки висвітлила I.С. Бородай [67]. Авторці вдалося відтворити еволюційний поступ основних зоотехнічних напрямів і вчень, розкрити внесок провідних наукових шкіл. У 30-х рр. ХХ ст. активно здійснювалася племінна справа, було зміцнено кормову базу, покращено умови утримання сільськогосподарських тварин та ін. Еволюцію наукової думки в механізації та автоматизації у тваринництві дослідив Р.В.Бей [68]. Автор зазначає, що упродовж 1930-х рр. питання механізації виробничих процесів у тваринництві було вперше поставлено на наукову основу, розпочали вивчення доїльних апаратів і обладнання зарубіжного виробництва, механізації процесів годівлі та типізації інкубаторів. У цей період впроваджували нові науково-організаційні форми, зростала кількість галузевих дослідних установ, які займалися конструюванням машин та розробкою науково-технічної документації для комплексної механізації сільського господарства, створенням методів проектування сільськогосподарських машин та ін.

Автором даної статті узагальнено та реконструйовано складний процес інституалізації 3 подальшою академізацією сільськогосподарської науки i дослідної справи в Україні [69; 70]. Доведено, що наприкінці 20-х - у 30-і рр. XX ст. відбулось ствердження й удосконалення науково-організаційних i методологічних засад функціонування сільськогосподарської науки. Напрацювання й здобутки освітніх і дослідницьких інституцій, вчених аграрної 
галузі здійснили регенеруючий вплив на компоненти еволюції аграрної науки України та вирішення засадничих питань наукового супроводу землеробства, рослинництва, тваринництва, економіки й механізації сільськогосподарського виробництва, збагатили науковий потенціал української спільноти, здатної розбудувати сталу структуру вітчизняного наукового простору.

Завершують виклад аналізу історіографічних праць комплексні видання історичного характеру «Аграрна історія України» [71] «Історія господарства: Україна і світ» [72], «Новітня аграрна історія України» [73], «Аграрна історія України: еволюція соціально-економічних відносин» [74]. Праці розкривають розвиток вітчизняної аграрної історії. Спираючись на результати наукового осмислення об'ємного фактологічного матеріалу, дослідники висвітлили основні етапи поступу аграрного розвитку України. У цих роботах проаналізовано суспільно-політичні, соціально-економічні та культурні сторони життя українського селянства без урахування стану наукового забезпечення аграрної галузі народного господарства.

Здійснений аналіз дає підстави стверджувати про достатній рівень опрацювання проблеми розвитку аграрної науки й дослідної справи наприкінці 20-х - у 30-і pp. ХХ ст. в Україні. Науковий обіг містить змістовні узагальнюючі праці, де в контексті розгляду складових галузевого дослідництва в історичній ретроспективі розкрито науково-організаційні форми забезпечення розвитку аграрної галузі України. Сприйняття та врахування усталеного поділу історіографічних досліджень відповідно до політичного устрою Української держави є цілком виправданими, особливо у відображенні методологічних проекцій дослідників. У цьому зв'язку спостерігаємо властиве радянському періоду певне нівелювання методу персоніфікації, біографічного і бібліографічного методів, а також принципів історичного пізнання. Проте це не зменшує цінності першої групи напрацювань, які коригують, або навіть формують основу історичних розвідок сучасних дослідників. Використання ними сучасного методологічного інструментарію, підкріплене архівною базою, в кінцевому результаті сприяє успішному виконанню функцій історичних наук. 
Активне опрацювання в останні десятиріччя проблеми історичного розвитку сільськогосподарської науки засвідчує зростання інтересу до пізнання й переосмислення історії української науки.

\section{Список використаних джерел та літератури}

1. Вергунов В. А. Історія сільськогосподарської дослідної справи в Україні. У 3 ч. / НААН, ННСГБ. Київ : Аграр. наука, 2018. Ч. 2 : Науковоорганізаційні засади функціонування сільськогосподарської дослідної справи на теренах України (друга половина XIX - початок XXI ст.). 620 с.

2. Бородай І. С. Серійні видання як джерела дослідження історії сільськогосподарської дослідної справи в Україні. Universum Historiae et Archeologiae. 2019. Vol. 2(27). Issue 1, pp. 194-204 doi 10.15421/26190116.

3. Винер В. В. Областное построение с.-х. опытного дела в теории и на практике. С.-х. опытное дело. 1925. № 6. С. 3-8.

4. Кулжинський С. Полтавська дослідна станція і дослідна справа Радянського Союзу. Земельник. 1925. Ч. 4-5. С. 83-85.

5. Соколовський О. Сільськогосподарська наука й життя (Уваги до проблеми організації с.-г. науки на Україні). Вісн. с.-г. науки. 1927. № 1. С. 919.

6. Яната О. А. Час заснувати Українську академію наук сільськогосподарських. Наука та техніка. 1925. № 2. С. 45-49.

7. Захаров С. А. Введение в агрономию. Москва; Ленинград : Госиздат, 1927. $210 \mathrm{c}$.

8. Смиренномудренский В. С. Введение в изучение агрономии. Ленинград : Изд-во «Мысль», 1925. 160 с.

9. Румянцев В. Дослідні станції та що вони дають селянству. Харків : Всеукр. с.-Г. вид-во «Радянський селянин», 1927. 122 с.

10. Румянцев В. М. Сельскохозяйственная наука на грани второй пятилетки. Москва ; Ленинград : Сельколхозгиз, 1932. 40 с.

11. Филиповський Ол-р. Сільськогосподарська дослідна справа : підр. для вищ. шкіл. Київ : Книгоспілка, 1928. 185 с.

12. Недокучаев Н. К. Возникновение, развитие и современное состояние опытного дела в СССР. Полевой метод. Краткое руководство по методике полевых опытов. Москва ; Ленинград : Сельхозгиз, 1930. С. 15-65.

13. Недокучаев Н. К. История сельскохозяйственного опытного дела. Опьтное дело в полеводстве. Теория и практика. Курс лекций. Москва: Госиздат, 1929. С. 15-42.

14. Машура С. Реконструкція науково-дослідної та дослідної справи в сільському господарстві. Спеціаліст сіл. госn-ва України. 1930. №1-2. С. 47-52.

15. Теплов I. До реконструкції науково-дослідної та дослідної справи (Порядком обговорення). Спеціаліст сіл. госп-ва Украӥни. 1930. № 3-4. С. 2528. 
16. Гомон Ю. Реконструкція сільськогосподарської дослідної справи на Україні (Порядком обговорення). Спеціаліст сіл. госп-ва України. 1930. № 5-6. C. 33-37.

17. Доповідь професора А.М. Сліпанського про завдання с.-г. науки в реконструктивний період. Завдання с.-2. науки в реконструктивний період. Доповідь $і$ промови на 1-му пленумі ВУАСГН 20 червня 1931 . Харків: Держсільгоспвидав, 1932. С. 10-27.

18. За підвищення врожайності : зб. ст. / НКЗС УСРР, ВУАСГН. Харків : Держсільгоспвидав, 1932. 108 с.

19. Махов Г. Г. Досягнення агрономічного грунтознавства УРСР за 1917 1937 рр. Зернове господарство. 1937. № 11-12. С. 76-81.

20. Виленский Д. Г. Советская наука о почве к XVII партийному съезду. Почвоведение. 1934. № 1. С. 5-28.

21. Научно исследовательский институт свиноводства. К итогам десятилетней работы Института. 1930-1940 / редкол. : П. К. Решетняк (ответ. ред.) [и др.]. Полтава, 1940. 72 с.

22. Дмитренко П. Т. Харьковский ордена Трудового Красного Знамени сельскохозяйственный институт. Записки Харьков. ордена Труд. Красного Знамени с.-х. ин-та (1840-1940). Харьков : Изд. Харьков. с.-х. ин-та, 1941. Т. 3. Вып. 1-2. Юбилейный. С. 1-13.

23. Константинов П. Н. Краткая история сельскохозяйственного опытного дела и современная структура его в СССР. Основы сельскохозяйственного опьттного дела. Москва : Гос. изд-во с.-х. лит-ры, 1952. С. 43-52.

24. Вербин А. А. У истоков отечественной агрономии. Москва : Сов. наука, 1955. $122 \mathrm{c}$.

25. Рожественский Б. Н. Методика опытно-исследовательского дела по полеводству / Укр. акад. с.-Х. наук, Укр. н.-и. ин-т растениеводства, селекции и генетики. Киев : Гос. изд-во с.-х. лит-ры, 1958. 220 с.

26. Сазанов В. И. Сельскохозяйственное опытное дело в растениеводстве и его методика. Москва : Сельхозгиз, 1962. 112 с.

27. Лавриненко Д. Д. Розвиток лісотипологічної науки на Україні. Вісн. аграр. науки. 1967. № 11. С. 93-100.

28. Поляков I. М. [та ін.] Успіхи українських селекціонерів у створенні нових сортів основних польових культур. Вісн. аграр. науки. 1967. № 11. С. 316.

29. Предисловие. Старейшее сельскохозяйственное научноисследовательское учреждение страны. Результаты научно-исследовательской работы Полтавской сельскохозяйственной опытной станции: выводы, рекомендации, внедрение дострижений науки и передового опыта / подгот. И.И. Власюк; Полтав. гос. с.-х. опит. ст., Полтав. обл. упр. НТО сел. хоз-ва. Харьков : Прапор, 1964. С. 3-19.

30. Исторический обзор и краткие результаты работ за 1854-1954 гг. Юбилейный сборник научных трудов, посвященный 70-летию Полтавской опьэтной станции - Украинского филиала Института кормов. 1884-1954 / под 
ред. М. П. Елсукова [и др.]; Всесоюз. н.-и. ин-т кормов им. В.Р. Вильямса, Укр. филиал ин-та кормов. Киев : Гос. изд-во с.-х. лит. Укр. ССР, 1959. С. 7-19.

31. Гринь Г. С. 3 історії територіальних грунтових досліджень на Україні. Агрохімія і трунтознавство. 1970. № 15. С. 3-16.

32. Слинько I. I. Соціалістична перебудова i технічна реконструкція сільського господарства України (1927-1932). Київ : Вид-во АН УРСР, 1961. $326 \mathrm{c}$.

33. Синягин И. И. Земледелие и растениеводство в России за 50 лет / Общво «Знание» РСФСР, Науч.-метод. Совет по пропаганде с.-х. знаний и передового опыта. Москва, 1967. 34 с.

34. Юрчишин В. В. та ін. Кузня сільськогосподарських кадрів / за заг. ред. В.В. Юрчишина. Київ : Урожай, 1973. 152 с.

35. Діденко В. В. Нарис історії Національного аграрного університету (До 100-річчя заснування). Київ : Аграр. наука, 1998. 173 с.

36. Чаянов А. В. Крестьянское хозяйство : избр. тр. / ред. кол. Л.И. Абалкин и др. Москва : Экономика, 1989. 492 с.

37. Никонов А. А. Спираль многовековой драмы : аграрная наука и политика России (XVIII-XX вв.). Москва : Энциклопедия рос. деревень, 1995. $574 \mathrm{c}$.

38. Иванов И. В. История отечественного почвоведения. Развитие идей, дифференциация, институализация. Кн. первая. 1870-1947 / Ин-т физикохимических и биологических проблем почвоведения, Докучаевское общество почвоведов. Москва : Наука, 2003. 397 с.

39. Василенко П. М. и др. Развитие механизации и электрификации сельского хозяйства Украинской ССР / АН УССР, Ин-т истории АН УССР. Киев: Наук. думка, 1988. 472 с.

40. Онопрієнко В. I. Історія української науки XIX-XX століть : навч. посіб. Київ : Либідь, 1998. 304 с.

41. Онопрієнко В. I. Репресована наука України. Київ : Тов-во «Знання», 1990. $32 \mathrm{c}$.

42. Ткаченко В. В. Діяльність науково-дослідних кафедр у вищих навчальних закладах та організація галузевої науки в УСРР у 1920-1930 роках. 2010. Гілея. Вип. 23. С. 75-83.

43. Созінов О. О. та ін. Сторінки історії. Українська академія аграрних наук. 1991-1995. Київ : Аграр. наук, 1996. С. 3-30.

44. Вчені в галузі тваринництва / наук. ред. Г.О. Богданов, В.П. Буркат. Київ : Аграр. наука. 1999. 423 с.

45. Вчені генетики-селекціонери та рослинники / Наук. ред. М.В. Роїк. Київ : Аграр. наука. 2003. 503 с.

46. Вчені грунтознавці, агрохіміки, землероби / наук. ред. О. Г. Тараріко, В.В. Медведєв. Київ : Аграр. наука, 2003. 332 с.

47. Вчені економісти-аграрники : у 2 ч. / наук. ред. М.В. Зубець, О.М. Шпичак, В.П. Ситник. Київ : Аграр. наука. 2001. 512 с.; 444 с

48. Вчені у галузях механізації, електрифікації та меліорації / наук. ред. М.К. Лінник, В.П. Буркат. Київ : Аграр. наука. 2000. 297 с. 
49. Вчені-генетики і селекціонери у галузі рослинництва / наук. ред. Ф.Ф. Адамень. Київ : Аграр. наука. 2000. 364 с.

50. Вчені-селекціонери у тваринництві / наук. ред. М.В. Зубець, В.П. Буркат. Київ : Аграр. наука. 1997. 249 с.

51. Генетика і селекція в Україні на межі тисячоліть : у 4 т. / редкол. : В.В. Моргун (голов. ред.) [та ін.] Київ : Логос, 2001. Т. 2. 636 с.

52. Вергунов В.А. Полтавське дослідне поле: становлення і розвиток сільськогосподарської дослідної справи в Україні (до 125-річчя державного дослідництва в агрономії та тваринництві) / УААН, ДНСГБ. Київ, 2009. 220 с.

53. Вергунов В. А. Сільськогосподарська дослідна справа в Україні. Від зародження до академічного існування: організаційний аспект / НАAН, ННСГБ. Київ : Аграр. наука, 2012. 416 с.

54. Яната Олександр Алоїзович (1888-1938) : біобібліогр. покажч. / УААН, ЦНСГБ, АН Вищої шк. України, Сектор історії та методології освіти, науки і техніки ; уклад. В. А. Вергунов [та ін.] ; наук. ред. О. Я. Пилипчук, В. А. Вергунов. Київ, 2001. 83 с.

55. Професор Махов (Махів) Григорій Григорович (1886-1952): бібл. покажчик наук. праць за 1914-1994 рр. / [уклад. та наук. ред. В. А. Вергунов]. Київ, 2005. 100 с.

56. Вергунов В. А., Новосад Н. М., Зозуля В. А., Новосад К. Б. Академік Олексій Никанорович Соколовський (1884-1959). Харків: К.П. «Друкарня № 13», 2006. 164 c.

57. Академік Квасницький Олексій Володимирович (1900-1989) : життєвий і творчий шлях / УААН, Ін-т свинарства ім. О.В. Квасницького, Полтав. держ. аграр. акад., ДНСГБ ; уклад. : В. Ф. Коваленко та ін. Полтава : «Полтавський літератор», 2005. 152 с.

58. Апостол М. В. Академік А. О. Сапєгін - подвижник та корифей вітчизняного природознавства першої половини ХХ ст. / НААН, ННСГБ, Ін-т історії аграр. науки, освіти та техніки ; наук. ред. В. А. Вергунов ; вступ. слово Я. М. Гадзала. Вінниця : ТОВ «Нілан-ЛТД», 2015. 186 с.

59. Вергунов В. А. Історія грунтознавства в Україні : проблеми i методологія шляхів вирішення. Вісн. Харків. нац. аграр. ун-ту ім. В. В. Докучаєва. 2006. № 7. С. 20-37.

60. Гринченко А. М. Кафедра почвоведения Харьковского государственного аграрного университета им. В.В. Докучаева : исторический очерк (1894-1979 гг.). Харьков, 1994. 35 с.

61. Сайко В. Ф. Становлення Інституту землеробства Української академії аграрних наук. Землеробство : міжвід. темат. наук. зб. [спецвипуск]. Київ : Нора-Прінт, 1999. № 73. С. 3-19.

62. Шелепов В. В. и др. Пшеница: история, морфология, биология, селекция. Киев, 2009. 573 с.

63. Піпан Х. М. Селекція озимої пшениці в Україні : історія та здобутки / НААН, ННСГБ ; за наук. ред. В. В. Шелепова. Київ : Нілан-ЛТД, 2013. 200 с. 
64. Коваленко Н. П. Становлення та розвиток науково-організаційних основ застосування вітчизняних сівозмін у системах землеробства (друга половина XIX - початок XXI ст.) / НААН, ННСГБ. Київ, 2014. 490 с.

65. Саблук П. Т. Аграрна економіка і політика в Україні : підсумки минулого та погляд у майбутне. Науково-популярні нариси у трьох томах. Т. 1. Економіка періоду диктатури влади. Київ : Ін-т аграр. економіки, 2001. 432 с.

66. Омельченко I. К., Гринник I. В. Садівнича наука України : минуле, сьогодення, перспективи / Ін-т садівництва НААН. Київ: «Преса України», 2012. $528 \mathrm{c}$.

67. Бородай I. С. Теоретико-методологічні основи становлення та розвитку вітчизняної зоотехнічної науки / НААН, ДНСГБ; наук. ред. В. А. Вергунов. Вінниця, 2012. 414 с.

68. Бей Р. В. Еволюція наукової думки в механізації та автоматизації у тваринництві УРСР (20-80-ті рр. ХХ ст.) / НААН, ННСГБ; наук. ред. В.А. Вергунов. Вінниця : ТОВ «Нілан-ЛТД», 2015. 380 с.

69. Щебетюк Н. Б. Історія Всеукраїнської академії сільськогосподарських наук (1931-1935) / НААН, ННСГБ. Київ, 2017. 158 с.

70. Щебетюк Н. Б. Розвиток аграрної науки України наприкінці 20-х - у 30-і pp. ХХ ст. ; НААН, ННСГБ, Ін-т історії аграр. науки, освіти та техніки ; наук. ред. В.А. Вергунов. Кам'янець-Подільський : «Друкарня «Рута»», 2017. $380 \mathrm{c}$.

71. Панченко П. П., Славов В. П., Шмарчук В. А. Аграрна історія України : навч. посіб. Київ : Просвіта, 1996. 406 с.

72. Історія господарства : Україна і світ : підручник / за ред. Б.Д. Лановика. Київ : Вища шк., 1995. 480 с.

73. Завальнюк О. М., Рибак I. В. Новітня аграрна історія України. Кам'янець-Подільський : Абетка-Нова, 2004. 287 с.

74. Панченко П. П. [та ін.] Аграрна історія України : еволюція соціальноекономічних відносин : навч. посіб. для студ. вищ. навч. закл. ; 2-ге вид., доп. і перероб. Київ : Аграр. наука, 2014. 536 с.

\section{References}

1. Verhunov V. A. (2018). Istoriia silskohospodarskoi doslidnoi spravy v Ukraini : u 3 ch. [History of agricultural research in Ukraine: in 3 parts]. Kyiv : Ahrar. nauka. Ch. 2 : Naukovo-orhanizatsiini zasady funktsionuvannia silskohospodarskoi doslidnoi spravy na terenakh Ukrainy (druha polovyna KhIKh pochatok KhKhI st.) [Scientific and organizational principles of functioning of agricultural research in Ukraine (second half of the XIX - beginning of the XXI century)]. 620. [in Ukrainian].

2. Borodai I. S. (2019). Seriini vydannia yak dzherela doslidzhennia istorii silskohospodarskoi doslidnoi spravy $\mathrm{v}$ Ukraini [Serial publications as sources of research on the history of agricultural research in Ukraine]. Universum Historiae et Archeologiae. Vol. 2(27). Issue 1, pp. 194-204. doi 10.15421/26190116. [in Ukrainian]. 
3. Vyner V. V. (1925). Oblastnoe postroenye s.-kh. opыtnoho dela v teoryy y na praktyke [Regional construction of agricultural research.in theory and practice]. S.-kh. opыtnoe delo [Agricultural research]. № 6.3-8. [in Russian].

4. Kulzhynskyi S. (1925). Poltavska doslidna stantsiia i doslidna sprava Radianskoho Soiuzu [Poltava Research Station and Research Case of the Soviet Union]. Zemelnyk [Landowner]. Ch. 4-5. 83-85. [in Ukrainian].

5. Sokolovskyi O. (1927). Silskohospodarska nauka y zhyttia (Uvahy do problemy orhanizatsii s.-h. nauky na Ukraini) [Agricultural science and life (Attention to the problem of organization of agricultural science in Ukraine)]. Visn. s.-h. Nauky [Bulletin of Agricultural Science]. № 1. 9-19. [in Ukrainian].

6. Yanata O. A. (1925). Chas zasnuvaty Ukrainsku akademiiu nauk silskohospodarskykh [It is time to establish the Ukrainian Academy of Agricultural Sciences]. Nauka ta tekhnika [Science and technology]. № 2. 45-49. [in Ukrainian].

7. Zakharov S. A. (1927). Vvedenye $\mathrm{v}$ ahronomyiu [Introduction to agronomy]. Moskva ; Lenynhrad : Hosyzdat. 210. [in Russian].

8. Smyrennomudrenskyi V.S. (1925). Vvedenye v yzuchenye ahronomyy [Introduction to the study of agronomy]. Lenynhrad : Yzd-vo «Mysl». 160. [in Russian].

9. Rumiantsev V. (1927). Doslidni stantsii ta shcho vony daiut selianstvu [Research stations and what they give to the peasantry]. Kharkiv : Vseukr. s.-h. vydvo «Radianskyi selianyn». 122. [in Ukrainian].

10. Rumiantsev V. M. (1932). Selskokhoziaistvennaia nauka na hrany vtoroi piatyletky [Agricultural science on the verge of the second five-year plan]. Moskva ; Lenynhrad : Selkolkhozghyz. 40. [in Russian].

11. Fylypovskyi Ol-r. (1928). Silskohospodarska doslidna sprava : pidr. dlia vyshch. Shkil [Agricultural research: a textbook for higher education]. Kyiv : Knyhospilka. 185. [in Ukrainian].

12. Nedokuchaev N. K. (1930). Voznyknovenye, razvytye y sovremennoe sostoianye opыtnoho dela v SSSR. Polevoi metod. Kratkoe rukovodstvo po metodyke polevыkh opыtov [The emergence, development and current state of experimental work in the USSR. Field method. A quick guide to field methodology]. Moskva ; Lenynhrad : Selkhozghyz. 15-65. [in Russian].

13. Nedokuchaev N. K. (1929). Ystoryia selskokhoziaistvennoho opыtnoho dela. Opttnoe delo v polevodstve. Teoryia y praktyka [The history of agricultural experimental work. Research in field cultivation. Theory and practice]. Kurs lektsyi. Moskva : Hosyzdat. 15-42. [in Russian].

14. Mashura S. (1930). Rekonstruktsiia naukovo-doslidnoi ta doslidnoi spravy v silskomu hospodarstvi [Reconstruction of research and development in agriculture]. Spetsialist sil. hosp-va Ukrainy [Agricultural specialist of Ukraine]. №1-2. 47-52. [in Ukrainian].

15. Teplov I. (1930). Do rekonstruktsii naukovo-doslidnoi ta doslidnoi spravy (Poriadkom obhovorennia) [Before the reconstruction of research and research case (Discussion procedure)]. Spetsialist sil. hosp-va Ukrainy [Agricultural specialist of Ukraine]. № 3-4. 25-28. [in Ukrainian]. 
16. Homon Yu. (1930). Rekonstruktsiia silskohospodarskoi doslidnoi spravy na Ukraini (Poriadkom obhovorennia) [Reconstruction of agricultural research in Ukraine (Discussion procedure)]. Spetsialist sil. hosp-va Ukrainy [Agricultural specialist of Ukraine]. № 5-6.33-37. [in Ukrainian].

17. Dopovid profesora A. M. Slipanskoho pro zavdannia s.-h. nauky v rekonstruktyvnyi period [Report of Professor A.M. Slipansky on the tasks of agricultural science in the reconstruction period]. Zavdannia s.-h. nauky $v$ rekonstruktyvnyi period. Dopovid i promovy na 1-mu plenumi AUAAS 20 chervnia 1931 r. [Tasks of agricultural science in the reconstruction period. Report and speeches at the 1st plenum of VUASGN June 20, 1931]. Kharkiv : Derzhsilhospvydav, 1932. 10-27. [in Ukrainian].

18. (1932) Za pidvyshchennia vrozhainosti : zb. st. [For increasing yields: a collection of articles] / NKZS USRR, VUASHN. Kharkiv : Derzhsilhospvydav. 108. [in Ukrainian].

19. Makhov H. H. (1937). Dosiahnennia ahronomichnoho gruntoznavstva URSR za 1917-1937 rr. [Achievements of agronomic soil science of the USSR for 1917-1937]. Zernove hospodarstvo [Grain economy]. № 11-12. 76-81. [in Ukrainian].

20. Vylenskyi D. H. (1934). Sovetskaia nauka o pochve k KhVII partyinomu şezdu [Soviet soil science for the 17th Party Congress]. Pochvovedenye [Soil science]. № 1. 5-28. [in Russian].

21. (1940). Nauchno yssledovatelskyi ynstytut svynovodstva. K ytoham desiatyletnei rabotы Ynstytuta. 1930-1940 [Research Institute of Pig Breeding. By the results of the ten-year work of the Institute. 1930-1940] / redkol. : P. K. Reshetniak (otvet. red.) [y dr.]. Poltava. 72. [in Russian].

22. Dmytrenko P. T. (1941). Kharkovskyi ordena Trudovoho Krasnoho Znameny selskokhoziaistvennыi ynstytut [Kharkov Agricultural Institute of the Order of the Red Banner of Labor]. Zapysky Kharkov Agricultural Institute of the Order of the Red Banner of Labor (1840-1940) [Notes Kharkov. Order of Labor. Of the Red Banner of S.-kh. Institute (1840-1940)]. Kharkov : Yzd. Kharkov. s.-kh. yn-ta. T. 3. Vыр. 1-2. Yubyleinыi. 1-13. [in Russian].

23. Konstantynov P. N. (1952). Kratkaia ystoryia selskokhoziaistvennoho opыtnoho dela y sovremennaia struktura eho v SSSR [A brief history of agricultural experimental work and its modern structure in the USSR]. Osnovb selskokhoziaistvennoho opttnoho dela [Fundamentals of agricultural experimental work]. Moskva : Hos. yzd-vo s.-kh. lyt-rы,. 43-52. [in Russian].

24. Verbyn A. A. (1955). U ystokov otechestvennoi ahronomyy [At the origins of Russian agronomy]. Moskva : Sov. nauka. 122. [in Russian].

25. Rozhestvenskyi B. N. (1958). Metodyka opыtno-yssledovatelskoho dela po polevodstvu [Research methodology for plant growing] / Ukr. akad. s.-kh. nauk, Ukr. n.-y. yn-t rastenyevodstva, selektsyy y henetyky. Kyev : Hos. yzd-vo s.-kh. lyt-rы. 220. [in Russian].

26. Sazanov V. Y. (1962). Selskokhoziaistvennoe opыtnoe delo v rastenyevodstve y eho metodyka [Agricultural experimental research in plant growing and its methodology]. Moskva : Selkhozghyz. 112. [in Russian]. 
27. Lavrynenko D. D. (1967). Rozvytok lisotypolohichnoi nauky na Ukraini [Development of forest typological science in Ukraine]. Visn. ahrar. Nauky [Bulletin of Agricultural Science]. № 11.93-100. [in Ukrainian].

28. Poliakov I. M. [ta in.] (1967). Uspikhy ukrainskykh selektsioneriv u stvorenni novykh sortiv osnovnykh polovykh kultur [Successes of Ukrainian breeders in creating new varieties of main field crops]. Visn. ahrar. Nauky [Bulletin of Agricultural Science]. № 11. 3-16. [in Ukrainian].

29. (1964). Predyslovye. Stareishee selskokhoziaistvennoe nauchnoyssledovatelskoe uchrezhdenye stranы [Foreword. The oldest agricultural research institution in the country]. Rezultatы nauchno-yssledovatelskoi rabotы Poltavskoi selskokhoziaistvennoi opыtnoi stantsyy : vыvodы, rekomendatsyy, vnedrenye dostryzhenyi nauky y peredovoho opыta [The results of the research work of the Poltava Agricultural Experiment Station: conclusions, recommendations, the introduction of scientific achievements and advanced experience] / podhot. Y.Y. Vlasiuk ; Poltav. hos. s.-kh. opyt. st., Poltav. obl. upr. NTO sel. khoz-va. Kharkov : Prapor. 3-19. [in Russian].

30. (1959). Ystorycheskyi obzor y kratkye rezultatы rabot za 1854-1954 hh. [Historical overview and brief results of work for 1854-1954.]. Yubyleinbi sbornyk nauchnыkh trudov, posviashchennыi 70-letyiu Poltavskoi opыtnoi stantsyy Ukraynskoho fylyala Ynstytuta kormov. 1884-1954 [Jubilee collection of scientific papers dedicated to the 70th anniversary of the Poltava Experimental Station - the Ukrainian branch of the Institute of Feed. 1884-1954] / pod red. M. P. Elsukova [y dr.]; Vsesoiuz. n.-y. yn-t kormov ym. V.R. Vyliamsa, Ukr. fylyal yn-ta kormov. Kyev : Hos. yzd-vo s.-kh. lyt. Ukr. SSR. 7-19. [in Russian].

31. Hryn H. S. (1970). Z istorii terytorialnykh gruntovykh doslidzhen na Ukraini [From the history of territorial soil research in Ukraine]. Ahrokhimiia i gruntoznavstvo [Agrochemistry and soil science]. № 15. 3-16. [in Ukrainian].

32. Slynko I. I. (1961). Sotsialistychna perebudova i tekhnichna rekonstruktsiia silskoho hospodarstva Ukrainy (1927-1932) [Socialist Perestroika and Technical Reconstruction of Agriculture in Ukraine (1927-1932)]. Kyiv : Vyd-vo AN URSR. 326. [in Ukrainian].

33. Syniahyn Y. Y. (1967). Zemledelye y rastenyevodstvo v Rossyy za 50 let [Agriculture and crop production in Russia for 50 years]. / Obshch-vo «Znanye» RSFSR, Nauch.-metod. Sovet po propahande s.-kh. znanyi y peredovoho opыta. Moskva. 34. [in Russian].

34. Yurchyshyn V. V. ta in. (1973). Kuznia silskohospodarskykh kadriv [Forge of agricultural personnel]. / za zah. red. V.V. Yurchyshyna. Kyiv : Urozhai. 152. [in Ukrainian].

35. Didenko V. V. (1998). Narys istorii Natsionalnoho ahrarnoho universytetu (Do 100-richchia zasnuvannia) [Essay on the history of the National Agrarian University (To the 100th anniversary of its foundation)]. Kyiv : Ahrar. nauka. 173. [in Ukrainian].

36. Chaianov A. V. (1989). Krestianskoe khoziaistvo : yzbr. tr. [Peasant economy: selected works]. / red. kol. L.Y. Abalkyn y dr. Moskva : Эkonomyka. 492. [in Russian]. 
37. Nykonov A. A. (1995). Spyral mnohovekovoi dramы : ahrarnaia nauka y polytyka Rossyy (KhVIII-KhKh vv.) [Turn of the centuries-old drama: agricultural science and politics of Russia (XVIII - XX centuries)]. Moskva : Эntsyklopedyia ros. dereven. 574. [in Russian].

38. Yvanov Y. V. (2003). Ystoryia otechestvennoho pochvovedenyia. Razvytye ydei, dyfferentsyatsyia, ynstytualyzatsyia. Kn. pervaia. 1870-1947 [History of Russian soil science. Development of ideas, differentiation, institutionalization. Book one. 1870-1947] / Yn-t fyzyko-khymycheskykh y byolohycheskykh problem pochvovedenyia, Dokuchaevskoe obshchestvo pochvovedov. Moskva : Nauka. 397. [in Russian].

39. Vasylenko P. M. y dr. (1988). Razvytye mekhanyzatsyy y эlektryfykatsyy selskoho khoziaistva Ukraynskoi SSR [Development of mechanization and electrification of agriculture in the Ukrainian SSR] / AN USSR, Yn-t ystoryy AN USSR. Kyev: Nauk. dumka. 472. [in Russian].

40. Onopriienko V. I. (1998). Istoriia ukrainskoi nauky KhIKh-KhKh stolit [History of the Ukrainian science of the 19th-20th century]. Kyiv : Lybid. 304. [in Ukrainian].

41. Onopriienko V. I. (1990). Represovana nauka Ukrainy [Repressed science of Ukraine]. Kyiv : Tov-vo «Znannia». 32. [in Ukrainian].

42. Tkachenko V. V. (2010). Diialnist naukovo-doslidnykh kafedr u vyshchykh navchalnykh zakladakh ta orhanizatsiia haluzevoi nauky v USRR u 1920-1930 rokakh [Activities of research departments in higher educational institutions and the organization of branch science in the USSR in 1920-1930]. Hileia. Vyp. 23. 75-83. [in Ukrainian].

43. Sozinov O. O. ta in. (1996). Storinky istorii [Pages of history]. Ukrainska akademiia ahrarnykh nauk. 1991-1995 [Ukrainian Academy of Agrarian Sciences. 1991-1995]. Kyiv : Ahrar. nauk. 3-30. [in Ukrainian].

44. (1999). Vcheni $\mathrm{v}$ haluzi tvarynnytstva [Scientists in the field of animal husbandry] / nauk. red. H. O. Bohdanov, V. P. Burkat. Kyiv : Ahrar. nauka. 423. [in Ukrainian].

45. (2003). Vcheni henetyky-selektsionery ta roslynnyky [Geneticists, breeders and botanists] / Nauk. red. M. V. Roik. Kyiv : Ahrar. nauka. 503. [in Ukrainian].

46. (2003). Vcheni gruntoznavtsi, ahrokhimiky, zemleroby [Soil scientists, agrochemists, farmers] / nauk. red. O. H. Tarariko, V. V. Medvediev. Kyiv : Ahrar. nauka. 512, 332. [in Ukrainian].

47. (2001). Vcheni ekonomisty-ahrarnyky: u 2 ch. [Agrarian economists: in 2 parts] / uporiad. i vidp. za vyp. O. V. Shatko. Kyiv : Ahrar. nauka. 512, 444. [in Ukrainian].

48. (2000). Vcheni u haluziakh mekhanizatsii, elektryfikatsii ta melioratsii [Scientists in the fields of mechanization, electrification and reclamation] / nauk. red. M. K. Linnyk, V. P. Burkat. Kyiv : Ahrar. nauka. 297. [in Ukrainian].

49. (2000). Vcheni-henetyky i selektsionery u haluzi roslynnytstva [Geneticists and breeders in the field of crop production] / nauk. red. F. F. Adamen. Kyiv : Ahrar. nauka. 364. [in Ukrainian]. 
50. (1997). Vcheni-selektsionery $u$ tvarynnytstvi [Scientists in the field of animal breeding and husbandry] / nauk. red. M. V. Zubets, V. P. Burkat. Kyiv : Ahrar. nauka. 249. [in Ukrainian].

51. (2001). Henetyka i selektsiia v Ukraini na mezhi tysiacholit : u 4 t. [Genetics and selection in Ukraine at the turn of the millennium: in 4 vols.] / redkol. : V. V Morhun (holov. red.) [ta in.]/ Kyiv : Lohos. T. 2. 636. [in Ukrainian].

52. Verhunov V. A. (2009). Poltavske doslidne pole: stanovlennia i rozvytok silskohospodarskoi doslidnoi spravy $\mathrm{v}$ Ukraini (do 125-richchia derzhavnoho doslidnytstva $\mathrm{v}$ ahronomii ta tvarynnytstvi) [Poltava research field: formation and development of agricultural research in Ukraine (to the 125th anniversary of state research in agronomy and animal husbandry)] / UAAN, DNSHB. Kyiv. 220. [in Ukrainian].

53 VerhunovV. A. (2012). Silskohospodarska doslidna sprava v Ukraini. Vid zarodzhennia do akademichnoho isnuvannia : orhanizatsiinyi aspekt [Agricultural research in Ukraine. From origin to academic existence: organizational aspect] / NAAN, NNSHB. Kyiv : Ahrar. nauka. 416. [in Ukrainian].

54. (2001). Yanata Oleksandr Aloizovych (1888-1938) : biobibliohr. pokazhch. [Yanata Oleksandr Aloizovych (1888-1938): biobibliographic index] / UAAN, TsNSHB, AN Vyshchoi shk. Ukrainy, Sektor istorii ta metodolohii osvity, nauky i tekhniky ; uklad. V. A. Verhunov [ta in.] ; nauk. red. O. Ya. Pylypchuk, V. A. Verhunov. Kyiv. 83. [in Ukrainian].

55.(2005). Profesor Makhov (Makhiv) Hryhorii Hryhorovych (1886-1952) : bibl. pokazhchyk nauk. prats za 1914-1994 rr. [Professor Makhov (Makhov) Hryhoriy Hryhorovych (1886-1952): bibliographic index of scientific works for 1914-1994.] / [uklad. ta nauk. red. V. A. Verhunov]. Kyiv. 100. [in Ukrainian].

56. Verhunov V. A. [ta in.] (2006). Akademik Oleksii Nykanorovych Sokolovskyi (1884-1959) [Academician Alexei Nikanorovich Sokolovsky (18841959)]. Kharkiv : K.P. «Drukarnia № 13». 164. [in Ukrainian].

57. (2005). Akademik Kvasnytskyi Oleksii Volodymyrovych (1900-1989) : zhyttievyi i tvorchyi shliakh [Academician Oleksiy Volodymyrovych Kvasnytsky (1900-1989): life and creative path] / UAAN, In-t svynarstva im. O.V. Kvasnytskoho, Poltav. derzh. ahrar. akad., DNSHB ; uklad. : V. F. Kovalenko ta in. Poltava : «Poltavskyi literator». 152. [in Ukrainian].

58. Apostol M. V. (2015). Akademik A. O. Sapiehin - podvyzhnyk ta koryfei vitchyznianoho pryrodoznavstva pershoi polovyny KhKh st. [Academician AA Sapegin - ascetic and luminary of domestic science of the first half of the twentieth century.] / NAAN, NNSHB, In-t istorii ahrar. nauky, osvity ta tekhniky ; nauk. red. V. A. Verhunov ; vstup. slovo Ya. M. Hadzala. Vinnytsia : TOV «Nilan-LTD». 186. [in Ukrainian].

59. Verhunov V. A. (2006). Istoriia gruntoznavstva v Ukraini : problemy i metodolohiia shliakhiv vyrishennia [History of soil science in Ukraine: problems and methodology of solutions]. Visn. Kharkiv. nats. ahrar. un-tu im. V. V. Dokuchaieva [Bulletin of Kharkiv National Agrarian University. VV Dokuchaev]. № 7. 20-37. [in Ukrainian]. 
60. Hrynchenko A. M. (1994). Kafedra pochvovedenyia Kharkovskoho hosudarstvennoho ahrarnoho unyversyteta ym. V. V. Dokuchaeva : ystorycheskyi ocherk (1894-1979 hh.) [Department of Soil Science, Kharkov State Agrarian University named after V.V. Dokuchaeva]. Kharkov. 35. [in Russian].

61.Saiko V. F. (1999). Stanovlennia Instytutu zemlerobstva Ukrainskoi akademii ahrarnykh nauk [Formation of the Institute of Agriculture of the Ukrainian Academy of Agrarian Sciences]. Zemlerobstvo [Agriculture]. [spetsvypusk]. Kyiv : Nora-Print. № 73. 3-19. [in Ukrainian].

62. Shelepov V. V. y dr. (2009). Pshenytsa: ystoryia, morfolohyia, byolohyia, selektsyia [Wheat: history, morphology, biology, breeding]. Kyev. 573. [in Russian].

63. Pipan Kh. M. (2013). Selektsiia ozymoi pshenytsi v Ukraini : istoriia ta zdobutky [Winter wheat breeding in Ukraine: history and achievements] / NAAN, NNSHB ; za nauk. red. V. V. Shelepova. Kyiv : Nilan-LTD. 200. [in Ukrainian].

64. Kovalenko N. P. (2014). Stanovlennia ta rozvytok naukovo-orhanizatsiinykh osnov zastosuvannia vitchyznianykh sivozmin u systemakh zemlerobstva (druha polovyna KhIKh - pochatok KhKhI st.) [Formation and development of scientific and organizational bases of application of domestic crop rotations in systems of agriculture (second half of the XIX - the beginning of the XXI century)] / NAAN, NNSHB. Kyiv. 490. [in Ukrainian].

65. Sabluk P. T. (2001). Ahrarna ekonomika i polityka v Ukraini : pidsumky mynuloho ta pohliad u maibutnie. Naukovo-populiarni narysy u trokh tomakh. T. 1 . Ekonomika periodu dyktatury vlady [Agrarian economy and politics in Ukraine: results of the past and a look into the future. Popular science essays in three volumes. T. 1. Economy of the period of dictatorship of power.]. Kyiv : In-t ahrar. ekonomiky. 432. [in Ukrainian].

66. Omelchenko I. K., Hrynnyk I. V. (2012). Sadivnycha nauka Ukrainy : mynule, sohodennia, perspektyvy [Horticultural science of Ukraine: past, present, prospects] / In-t sadivnytstva NAAN. Kyiv : «Presa Ukrainy». 528. [in Ukrainian].

67. Borodai I. S. (2012). Teoretyko-metodolohichni osnovy stanovlennia ta rozvytku vitchyznianoi zootekhnichnoi nauky [Theoretical and methodological bases of formation and development of domestic zootechnical science] / NAAN, DNSHB ; nauk. red. V. A. Verhunov. Vinnytsia. 414. [in Ukrainian].

68. Bei R. V. (2015). Evoliutsiia naukovoi dumky v mekhanizatsii ta avtomatyzatsii u tvarynnytstvi URSR (20-80-ti rr. KhKh st.) [Evolution of scientific thought in mechanization and automation in animal husbandry of the USSR (20-80s of the XX century)] / NAAN, NNSHB ; nauk. red. V. A. Verhunov. Vinnytsia : TOV «Nilan-LTD». 380. [in Ukrainian].

69. Shchebetiuk N. B. (2017). Istoriia Vseukrainskoi akademii silskohospodarskykh nauk (1931-1935) [History of the All-Ukrainian Academy of Agricultural Sciences (1931-1935] / NAAN, NNSHB. Kyiv. 158. [in Ukrainian].

70. Shchebetiuk N. B. (2017). Rozvytok ahrarnoi nauky Ukrainy naprykintsi 20$\mathrm{kh}-\mathrm{u} 30-\mathrm{i}$ rr. KhKh st. [The development of agricultural science in Ukraine in the late 20's - 30's of the twentieth century]: monohrafiia ; NAAN, NNSHB, In-t istorii ahrar. nauky, osvity ta tekhniky ; nauk. red. V. A. Verhunov. Kam'ianets-Podilskyi : «Drukarnia «Ruta»». 380. [in Ukrainian]. 
71. Panchenko P. P., Slavov V. P., Shmarchuk V. A. (1996), Ahrarna istoriia Ukrainy : navch. posib [Agrarian history of Ukraine: a textbook]. Kyiv : Prosvita. 406. [in Ukrainian].

72. (1995). Istoriia hospodarstva : Ukraina i svit : pidruchnyk [History of economy: Ukraine and the world: a textbook] / za red. B.D. Lanovyka. Kyiv : Vyshcha shk. 480. [in Ukrainian].

73. Zavalniuk O. M., Rybak I. V. (2004). Novitnia ahrarna istoriia Ukrainy [Recent agrarian history of Ukraine]. Kam'ianets-Podilskyi : Abetka-Nova. 287. [in Ukrainian].

74. Panchenko P. P. [ta in.] (2014). Ahrarna istoriia Ukrainy : evoliutsiia sotsialno-ekonomichnykh vidnosyn : navch. posib. dlia stud. vyshch. navch. zakl. [Agrarian history of Ukraine: the evolution of socio-economic relations: a textbook for students of higher educational institutions] ; 2-he vyd., dop. i pererob. Kyiv : Ahrar. nauka. 536. [in Ukrainian].

\section{Рецензент:}

Коцур Н. I., д.і.н., професор

Куйбidа В. В., д.і.н., професор

Надійшла до редакції 19.05.2020 р. 